\title{
Morphological and flowering characteristics of shallot (allium cepa var. Aggregatum) in response to gibberellic acid and vernalization
}

\author{
Marlin Marlin ${ }^{1 *}$, Hartal Hartal ${ }^{2}$, Atra Romeida ${ }^{1}$, Reny Herawati ${ }^{1}$, Marulak Simarmata ${ }^{1}$ \\ ${ }^{1}$ Department of Crop Production, Faculty of Agriculture, University of Bengkulu, Indonesia, ${ }^{2}$ Department of Plant Protection, Faculty of \\ Agriculture, University of Bengkulu, Indonesia, Jl. WR Supratman Kandang Limun Bengkulu, Indonesia 38121
}

\section{A B S TR A C T}

Shallot plants have variations in morphological and flowering characters. Flowering ability can be induced by the treatment of gibberellic acid $\left(\mathrm{GA}_{3}\right)$ and exposing to cold temperature (vernalization). The objectives of the research were to determine the effect of $\mathrm{GA}_{3}$ and vernalization on the morphological and flowering characters of 5 shallot varieties. Field study was organized in a completely randomized block design with three replications to evaluate the responses of 5 varieties of shallots (Bauji, Bima Brebes, Super Philip, Tajuk, and Thailand) to $\mathrm{GA}_{3}$ with the concentrations ranged from zero to $150 \mathrm{mg} \mathrm{L}^{-1}$. Plants were maintained for 65 days until harvesting. The second study was organized in a completely randomized design with 3 replications to evaluate the responses of the five varieties of shallot to vernalization. The vernalization of shallot bulbs were done at $8{ }^{\circ} \mathrm{C}$ for 6 weeks. The results indicated that a Super Phillip variety showed the highest response to $\mathrm{GA}_{3}$ observed in the number of leaves and bulbs. At $100 \mathrm{mg} \mathrm{L}^{-1}$ of $\mathrm{GA}_{3}$ increased the plant height up to $45.74 \mathrm{~cm}$. The results from the second study showed that vernalization was effective to increase flowering only on the llokos variety. But the other varieties were not sensitive to vernalization. Based on morphological and flowering characters, 5 varieties of shallots were clustered into 3 groups, namely: sensitive flowering included Bentanis, Bma Brebes and Tajuk variety, medium sensitive flowering included Ilokos variety, and non-sensitive flowering included Sumenep variety.

Keywords: Flower induction; Gibberellic acid; Shallot varieties; Vernalization

\section{INTRODUCTION}

Shallot (Allium cepa var. Aggregatum) is one of the economically important crop belong in the Liliaceae family. Shallot bulb contains important nutritive vegetable and medicinal (Mohammadi-Motlagh et al., 2011; Marlin et al., 2019). Shallot cultivation requires specific edaphoclimatic conditions and agricultural management to grow, overcome bulb dormancy, induce flower development, reproduce bulbs, and true seeds (Tendaj and Mysiak, 2013; Farhadi and Salteh, 2018).

Shallot responses to agricultural management and environmental conditions differ among different variety. Selection of the elite variety is an essential for obtaining desired growth and quality of bulbs, and induces the flower formation. The varieties of shallot in Indonesia have the ability to produce flowers, except for the Sumenep variety (Marlin et al., 2018). Cultivation techniques for developing shallot flowering initiation have not been widely developed. Shallot growth and development can be induced by optimizing genetic ability and manipulating the growing environment.

Treatments to induce flowering and seed formation can be carried out using growth regulators such as gibberellic acid and vernalization treatments. Gibberellic acid and vernalization treatment play a role in the plant growth and the process of flowering initiation. Both treatments work by stimulating the formation of flowering genes such as the SOC1 gene (suppressor of overexpression of constant 1) and the LEAFY gene (Corbesier and Coupland, 2006). The LEAFY gene is the main gene that controls flowering in shallot and predicticably have been related to flowering pattern (Marlin et al., 2018).

Bio-regulators like gibberellic acid $\left(\mathrm{GA}_{3}\right)$ have been known to play a vital role in building of plants and involved in 
plant growth together with stem elongation (Rahman et al., 2006), and the transition from vegetative growth to flowering (Sumarni et al., 2013).

The treatment at low temperatures (vernalization) can stimulate flower formation (Song et al., 2012). Vernalization is an important adaptation of plants to initiate flowering in response to prolonged exposure to low temperatures (Finnegan et al., 2001; Song et al., 2012). Elsiddig et al. (2015) showed that vernalization treatment at a temperature of $4-5^{\circ} \mathrm{C}$ for 90 days was a major factor to induce flowering in Texas Grano cultivar onions. The use of gibberellins and vernalization treatments to stimulate the growth and flowering for shallot has not been described. This studies were conducted to determine the effect of applying $\mathrm{GA}_{3}$ and vernalization in stimulating plant growth and flower initiation of shallot (Allium cepa var. Aggregatum).

\section{MATERIALS AND METHODS}

\section{Experimental 1}

\section{Experimental site and layouts}

Field experiment was carried out in the field located in $700 \mathrm{~m}$ above sea level in the planting season of 2019 and 2020. The experimental land was cultivated and made into a mound of plots measuring $100 \mathrm{~cm}$ x $120 \mathrm{~cm}$ each, and $30 \mathrm{~cm}$ height. The soil was mixed with manure at 10 tons ha ${ }^{-1}$ and the plots covered with silver black plastic. Planting spacing was $20 \mathrm{~cm} \times 20 \mathrm{~cm}$. Inorganic fertilizers of urea, super phosphat-36, and potassium chloride were given as basic fertilizers, at 250,150, and $150 \mathrm{~kg} \mathrm{ha}^{-1}$, respectively.

The experiment with two factors was organized in a randomized complete block design with three replications. The first factor was 5 varieties of shallots, namely Bauji, Bima Brebes, Super Philip, Tajuk, and Thailand. The second factor was the concentration of $\mathrm{GA}_{3}$ which were 50, 100,150 $\mathrm{mg} \mathrm{L}^{-1}$, and without $\mathrm{GA}_{3}$ as a control.

\section{Experimental material}

Five varieties of local shallot, namely Bauji, Bima Brebes, Super Philip, Tajuk, and Thailand were used as planting material. The average size of the bulbs was 3-5 grams. Shallot bulbs were cut off one third on the bulb top, and then soaked for one hour in the $\mathrm{GA}_{3}$ solution with concentration as described previously. Then, the shallot bulbs were planted through the holes by immersing the bulb into the soil and covering with a thin layer of soil. Plant maintenances included watering and controlling pests with pesticides were done before harvesting at 65 days after planting. Harvesting was done in the morning or during sunny conditions by carefully pulling the shallot plants.

\section{Data collection and analysis}

Observation was carried out on the growth and yield variables, which included: plant height, number of leaves, number of tillers, bulb diameter, number of bulbs, fresh weight of bulb, and dry weight of bulb. Data were collected from selected plants in each unit plot. To avoid border effect with the highest precision, 10 plants were selected randomly from each plot. Data were statistically analyzed with ANOVA at 5\% using SAS program version 9.1, and further tested by a Least Significance Different (LSD) test at a $95 \%$ confidence level.

\section{Experiment 2}

\section{Experimental site and layouts}

The experiment was carried out in a completely randomized design, with two factors. The first factor was 5 varieties of shallot as described previously and the second factor was vernalization treatment, which was with and without vernalization of the shallot bulbs. Vernalization was carried in storage room for 6 weeks at $8^{\circ} \mathrm{C}$. The shallot bulbs were planted in polybags with a diameter of $45 \mathrm{~cm}$ containing $10 \mathrm{~kg}$ of planting medium (which was mixed of soil, manure, and rice husk in ratio of $=2: 1: 1)$. Each polybag was planted with three shallot bulbs. The plants were fertilized with NPK mixture fertilizer (15:15:15) at a $2.4 \mathrm{~g}$ per polybag, or similar to $600 \mathrm{~kg}$. ha ${ }^{-1}$. Plant maintenances were carried out similar to previous experiment. The shallot bulbs were harvested at 65 days after planting.

\section{Experimental material}

Five varieties of local shallot as described previously were used as planting material. Before planting, the shallot bulbs were immersed for 15 minutes in a fungicide solution containing Benomyl 2 g. $\mathrm{L}^{-1}$ for 15 minutes. Then, the shallot bulbs were soaked again for another 15 minutes in the PGPR (plant growth promoting rbizobacteria) solution at $5 \mathrm{~g}$. $\mathrm{L}^{-1}$. The shallot bulbs were planted and maintenance as described previously.

\section{Data collection and analysis}

Morphological characters of the bulb weight were carried out by weighing the bulb before planting, while the characters of plant height, number of tillers, number of leaves were observed at 5 weeks after transplanting. Flowering characters observed as sprouting time, time to flowering, number of umbels, umbel diameter, length of umbel stalk, and time to umbel broke, were done when $75 \%$ of the plants shown those characteristics. The percentage of flowering plants was observed by counting the number of flowering plants divided by the number of plants for each treatment in each replication.

Data were analyzed statistically using ANOVA to determine the effect of vernalization on the morphological and 
flowering characters. Further analysis was carried out based on Least Significance Different (LSD) test with a 95\% confidence level. The analysis using the SAS program version 9.1. A cluster analysis was conducted using an unweighted pair group method arithmetic with means (UPGMA). This analysis was conducted with the Cluster package from the $\mathrm{R}$-software package ( $\mathrm{R}$ version 3.2.2).

\section{RESULTS AND DISCUSSION}

\section{The effect of gibberellic acid on shallot growth and yield}

The results of the analysis of variance on growth and yield of shallot showed the interaction between $\mathrm{GA}_{3}$ application and shallot varieties which observed significantly effects on the number of leaves, and number of bulbs. The further analysis with LSD test is presented in Table 1. A higher response of the number of leaves and bulbs at all $\mathrm{GA}_{3}$ concentrations were observed on Super Phillip variety. Meanwhile, Bima Brebes had the highest number of leaves and bulbs at 100-150 $\mathrm{mg} \mathrm{L}^{-1} \mathrm{GA}_{3}$. The plant growth regulators might be needed to increase shallot production, however $\mathrm{GA}_{3}$ influenced growth by promoting elongation of stem and internodes of plant. Sravani et al. (2020) reported that the highest plant was obtained under the treatment of $\mathrm{GA}_{3}$ at $25 \mathrm{mg}$. $\mathrm{L}^{-1}$. This might be due to the increasing of cell wall extensibility by $\mathrm{GA}_{3}$. Application of the exogenously $\mathrm{GA}_{3}$

Table 1: Interaction between GA3 concentrations and 5 varieties of shallots on the number of leaves and bulbs of shallot

\begin{tabular}{|c|c|c|c|}
\hline Variety & $\begin{array}{l}\text { Concentration } \\
\text { of } \mathrm{GA}_{3}\left(\mathrm{mg} \mathrm{L}^{-1}\right)\end{array}$ & $\begin{array}{l}\text { Number of } \\
\text { leaves }\end{array}$ & Number of bulbs \\
\hline \multirow[t]{4}{*}{ Bauji } & 0 & $21.60 \pm 0.14^{\mathrm{e}}$ & $5.60 \pm 0.15^{d}$ \\
\hline & 50 & $27.63 \pm 0.09^{d}$ & $5.87 \pm 0.09^{d}$ \\
\hline & 100 & $32.87 \pm 0.08^{c}$ & $7.03 \pm 0.00^{\mathrm{cd}}$ \\
\hline & 150 & $27.73 \pm 0.00^{d}$ & $6.15 \pm 0.08^{d}$ \\
\hline \multirow{4}{*}{$\begin{array}{l}\text { Bima } \\
\text { Brebes }\end{array}$} & 0 & $41.93 \pm 0.06^{b c}$ & $8.41 \pm 0.03^{b c}$ \\
\hline & 50 & $39.46 \pm 0.00^{\mathrm{bc}}$ & $8.67 \pm 0.09^{b c}$ \\
\hline & 100 & $48.53 \pm 0.20^{\mathrm{ab}}$ & $10.68 \pm 0.06^{\mathrm{abc}}$ \\
\hline & 150 & $32.13 \pm 1.00^{c}$ & $10.12 \pm 0.06^{\mathrm{abc}}$ \\
\hline \multirow{4}{*}{$\begin{array}{l}\text { Super } \\
\text { Philip }\end{array}$} & 0 & $48.93 \pm 0.01^{\mathrm{ab}}$ & $9.25 \pm 0.03^{b c}$ \\
\hline & 50 & $52.93 \pm 0.07^{a}$ & $12.50 \pm 0.03^{a b}$ \\
\hline & 100 & $56.60 \pm 0.03^{a}$ & $14.35 \pm 0.08^{a}$ \\
\hline & 150 & $44.20 \pm 0.08^{b}$ & $11.21 \pm 0.05^{\mathrm{abc}}$ \\
\hline \multirow[t]{4}{*}{ Tajuk } & 0 & $40.06 \pm 0.00^{b c}$ & $10.55 \pm 0.03^{\mathrm{abc}}$ \\
\hline & 50 & $39.13 \pm 0.08^{b c}$ & $8.36 \pm 0.05^{b c}$ \\
\hline & 100 & $33.80 \pm 0.01^{c}$ & $7.91 \pm 0.03^{c}$ \\
\hline & 150 & $44.46 \pm 0.06^{b}$ & $10.83 \pm 0.00^{\mathrm{abc}}$ \\
\hline \multirow[t]{4}{*}{ Thailand } & 0 & $31.60 \pm 0.01^{c}$ & $8.05 \pm 0.02^{\mathrm{bc}}$ \\
\hline & 50 & $40.16 \pm 0.05^{b}$ & $9.12 \pm 0.08^{\mathrm{bc}}$ \\
\hline & 100 & $38.87 \pm 0.08 b^{c}$ & $8.23 \pm 0.08^{b c}$ \\
\hline & 150 & $36.66 \pm 0.00 b^{c}$ & $8.87 \pm 0.04^{\mathrm{bc}}$ \\
\hline
\end{tabular}

The numbers followed by the same letter within each column are not significantly different based on the LSD test at $5 \%$ level. Values are means with standard deviation of triplicate determinations might have activated the endogenous hormonal activities which ultimately led to leaf elongation of plant.

Gibberellic acid $\left(\mathrm{GA}_{3}\right)$ is one of the main regulators of the growth and development of plants which stimulates not only the growth and promoting of cell division and elongation (Olszewski et al., 2002), but also plays a major role in diverse growth processes including seed development, organ elongation, senescence and control of flowering time (Yamaguchi 2008; Ouzounidou et al., 2011). The increase in the number of leaves per plant is mainly due to the enhancement of cell elongation and cell division. It enhances also the photosynthesis and respiration which catalyze the metabolism activities in plant. The results are conformed with the findings of earlier reports in onion (Hye et al., 2002; Tiwari et al., 2003; Patel et al., 2010;), and garlic (Singh et al., 2014; Govind et al., 2015).

Five varieties of shallot showed different growth and yield variables (Table 2). The variety of Tajuk showed the highest plant height $(43.3 \mathrm{~cm})$ and had the highest number of shoots per plant (8.1 shoots). Tajuk variety also showed higher yield compared to other varieties. It had the highest responses in the number of bulbs (9.41 bulbs/plant), bulb fresh weight (90.1 g/plant) and bulb net weight $(75 \mathrm{~g} /$ plant $)$.

The application of $\mathrm{GA}_{3}$ singly had no significant effect on another growth and yield of shallot (Table 3). These results are similar to those reported in garlic, observed that the plant height or the stem length at 15 and 25 days after planting were not significantly different among various concentration of $\mathrm{GA}_{3}$ (Rahman et al., 2006). However, the results showed that the plant heights were observed of 44.61-45.74 with the application of $\mathrm{GA}_{3}$ at $0-100 \mathrm{mg} \mathrm{L}^{-1}$, while the application of $\mathrm{GA}_{3}$ at $150 \mathrm{mg} \mathrm{L}^{-1}$ was only $40.11 \mathrm{~cm}$. Shaikh et al., (2002) reported that the application of $\mathrm{GA}_{3}$ at $50 \mathrm{mg} \mathrm{L}^{-1}$ to large or medium bulbs produced a significantly higher seed yield per hectare, germination and vigour values on onion. Kucera et al. (2005) showed that the applications of $\mathrm{GA}_{3}$ on plants increased the total plant height of onion and garlic by $35 \%$ and $25 \%$ of the control, respectively.

Helaly et al. (2016) reported that $\mathrm{GA}_{3}$ application on Allium cepa did not significantly affect the plant fresh weight, but increased the number of leaves, plant height and could allow for higher plant density, therefore higher total yield. A vigorous onion and garlic growth and yield were promoted by $\mathrm{GA}_{3}$ application (Kucera et al., 2005; Ouzounidou et al., 2011). GA 3 application stimulated and integrated the overall growth, development and reproduction of shallot. 
Table 2: Morphological characters on 5 varieties of shallots

\begin{tabular}{lccccrcc}
\hline Variety & $\begin{array}{c}\text { Plant height } \\
(\mathbf{c m})\end{array}$ & $\begin{array}{c}\text { Number of } \\
\text { leaves }\end{array}$ & $\begin{array}{c}\text { Number of } \\
\text { shoots }\end{array}$ & $\begin{array}{c}\text { Bulb diameter } \\
(\mathbf{c m})\end{array}$ & $\begin{array}{c}\text { Number of } \\
\text { bulbs }\end{array}$ & $\begin{array}{c}\text { Bulb fresh } \\
\text { weight }(\mathbf{g})\end{array}$ & $\begin{array}{c}\text { Bulb net } \\
\text { weight }(\mathbf{g})\end{array}$ \\
\hline Bauji & $32.6 \pm 0.08^{\mathrm{c}}$ & $24.1 \pm 0.05^{\mathrm{c}}$ & $4.7 \pm 0.10^{\mathrm{ab}}$ & $19.8 \pm 0.01^{\mathrm{a}}$ & $5.6 \pm 0.02^{\mathrm{c}}$ & $26.1 \pm 0.08^{\mathrm{c}}$ & $24.4 \pm 0.05^{\mathrm{c}}$ \\
Bima Brebes & $33.0 \pm 0.03^{\mathrm{c}}$ & $40.5 \pm 0.08^{\mathrm{b}}$ & $4.7 \pm 0.08^{\mathrm{b}}$ & $18.5 \pm 0.08^{\mathrm{a}}$ & $9.6 \pm 0.03^{\mathrm{b}}$ & $41.6 \pm 0.08^{\mathrm{bc}}$ & $40.3 \pm 0.08^{\mathrm{b}}$ \\
Super Philip & $38.1 \pm 0.08^{\mathrm{b}}$ & $50.6 \pm 0.00^{\mathrm{a}}$ & $6.3 \pm 0.00^{\mathrm{ab}}$ & $16.7 \pm 0.00^{\mathrm{a}}$ & $11.8 \pm 0.00^{\mathrm{a}}$ & $50.2 \pm 0.00^{\mathrm{b}}$ & $33.2 \pm 0.08^{\mathrm{bc}}$ \\
Tajuk & $45.3 \pm 0.01^{\mathrm{a}}$ & $39.6 \pm 0.08^{\mathrm{b}}$ & $8.1 \pm 0.07^{\mathrm{a}}$ & $20.8 \pm 0.05^{\mathrm{a}}$ & $9.4 \pm 0.00^{\mathrm{b}}$ & $90.1 \pm 0.02^{\mathrm{a}}$ & $75.0 \pm 0.00^{\mathrm{a}}$ \\
Thailand & $38.4 \pm 0.08^{\mathrm{b}}$ & $32.0 \pm 0.04^{\mathrm{bc}}$ & $5.6 \pm 0.06^{\mathrm{ab}}$ & $17.2 \pm 0.00^{\mathrm{a}}$ & $8.0 \pm 0.08^{\mathrm{b}}$ & $44.2 \pm 0.08^{\mathrm{bc}}$ & $34.7 \pm 0.04^{\mathrm{bc}}$ \\
\hline
\end{tabular}

The numbers followed by the same letter within each column are not significantly different based on the LSD test at $5 \%$ level. Values are means with standard deviation of triplicate determinations

Table 3: Morphological response of shallots at different GA3 concentrations

\begin{tabular}{|c|c|c|c|c|c|c|c|}
\hline $\begin{array}{l}\text { Concentration of } \mathrm{GA}_{3} \\
\left(\mathrm{mg} \mathrm{L}^{-1}\right)\end{array}$ & $\begin{array}{l}\text { Plant height } \\
(\mathrm{cm})\end{array}$ & $\begin{array}{c}\text { Number of } \\
\text { leaves }\end{array}$ & $\begin{array}{l}\text { Number of } \\
\text { shoots }\end{array}$ & $\begin{array}{l}\text { Bulb diameter } \\
(\mathrm{cm})\end{array}$ & $\begin{array}{c}\text { Number of } \\
\text { bulbs }\end{array}$ & $\begin{array}{l}\text { Bulb fresh weight } \\
(\mathrm{g})\end{array}$ & $\begin{array}{l}\text { Bulb net weight } \\
(\mathrm{g})\end{array}$ \\
\hline 0 & $45.7 \pm 0.00^{a}$ & $43.6 \pm 0.08^{a}$ & $8.0 \pm 0.12^{a}$ & $1.8 \pm 0.10^{\mathrm{a}}$ & $9.4 \pm 0.00^{\mathrm{a}}$ & $51.0 \pm 0.00^{a}$ & $38.4 \pm 0.03^{a}$ \\
\hline 50 & $44.6 \pm 0.08^{a}$ & $43.8 \pm 0.06^{a}$ & $8.8 \pm 0.08^{a}$ & $1.7 \pm 0,08 .^{a}$ & $9.9 \pm 0.08^{a}$ & $50.0 \pm 0.03^{a}$ & $34.2 \pm 0.08^{a}$ \\
\hline 100 & $41.9 \pm 0.06^{\mathrm{ab}}$ & $46.3 \pm 0.00^{a}$ & $8.9 \pm 0.08^{a}$ & $1.8 \pm 0.06^{a}$ & $11.6 \pm 0.10^{a}$ & $52.1 \pm 0.03^{a}$ & $38.7 \pm 0.00^{a}$ \\
\hline 150 & $40.1 \pm 0.05^{b}$ & $40.3 \pm 0.08^{a}$ & $8.2 \pm 0.05^{\mathrm{a}}$ & $1.7 \pm 0.10^{\mathrm{a}}$ & $10.3 \pm 0.10^{a}$ & $43.8 \pm 0.00^{a}$ & $31.5 \pm 0.00^{a}$ \\
\hline
\end{tabular}

The numbers followed by the same letter within each column are not significantly different based on the LSD test at $5 \%$ level. Values are means with standard deviation of triplicate determinations

\section{The Effect of Vernalization on Growth and Flower Initiation of Shallot}

The ANOVA showed that there was an interaction between vernalization treatment and the variety of shallot observed on time to sprout and the flowering characters of shallot. The interactions were able to increase the number of umbel, the diameter of umbel, the length of umbel stalk, and time to umbel broke in all varieties except Sumenep variety (Fig. 1).

The flowering ability of shallot depends on the genetic variability and environmental conditions. The vernalization treatment can stimulate flowering and produce more seeds (Khokhar, 2014). The vernalization signal received by plants is permanent and persists in subsequent crop development (Song et al., 2012). Plant growth environment becomes exogenous factors which has a strong influence in determining the ability of flowering. Inflorence develops from the apical meristem under suitable conditions.

The interaction between variety and vernalization gave a significantly different effect on the flowering quantitative character of shallot. Observations on the quantative characters of flowering showed that the Ilokos variety was responsive to vernalization treatment. While the Sumenep variety was not sensitive to flowering. There was no increase in all flowering characters in the Sumenep variety. The interaction effect between variety and vernalization treatment was able to increase umbel diameter characters in the varieties of Bima Brebes, Ilokos and Tajuk (Fig. 1G). The reports by Mardiana (2016) and Kusumadewi et al. (2017) showed that vernalization was effective in increasing flowering of shallot.

The average of shallot flowering without vernalization was $20 \%$, while with vernalization increased up to $39 \%$. The Bentanis variety showed no difference in the percentage

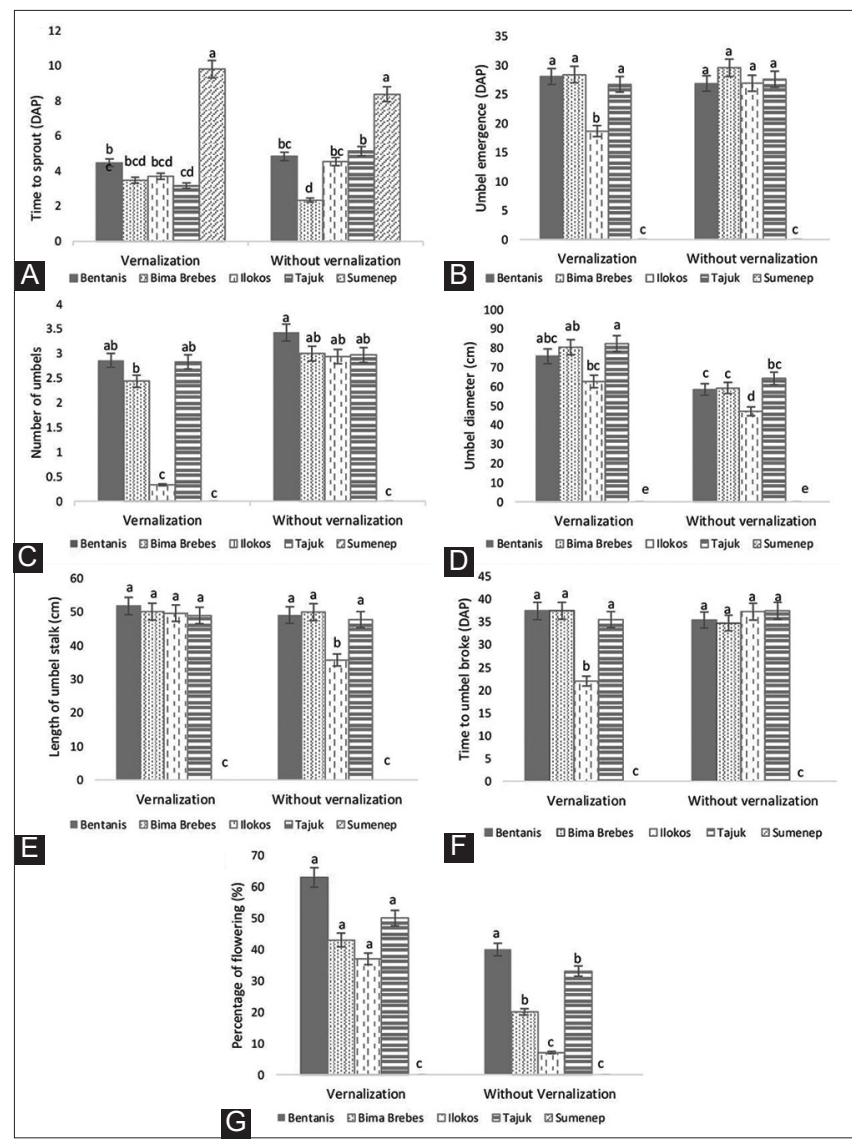

Fig 1. The interaction between shallot varieties and vernalization on time to sprout $(A)$, day of umbel emergence $(B)$, number of umbel (C), umbel diameter (D), length of umbel stalk (E), time to umbel broke $(F)$, and percentage of flowering $(G)$ of shallot. Values are means with standard deviation of triplicate determinations. Means with different lowercase letter are significantly different at on LSD test at 5\% level. Values are means with standard deviation of triplicate determinations

of flowering between those treated or not treated with vernalization. This indicated that the Bentanis variety 
is a sensitive variety to flowering, and able to produce flowers in all growing conditions. The result showed the importance of vernalization treatment to initiate flowering which might relate to the temperate origin of shallot. It had been reported by Lee et al. (2013) and Marlin et al. (2018) that vernalization blocked flowering repressor and induced expression of genes responsible for the flowering (florigen). Vernalization could also promote the upregulation of some key cytokinin signaling regulators which induced flowering (Wen et al., 2017). In contrast to the Sumenep variety that it was not able to increase the ability of flowering even though it was treated with vernalization.

The results showed that variety had a significant effect on the character of the initial bulb weight, time to flowering, umbel number, umbel diameter, length of umbel stalk, and the percentage of flowering (Fig. 2). The LSD test results showed that the varieties of Bentanis, Bima Brebes and Tajuk had higher initial tuber weights (5.43-6.80 g) compared to the Ilokos and Sumenep variety (3.31-3.65 g). The variety of Bentanis, Bima Brebes and Tajuk were higher than those of Ilokos and Sumenep. It was suspected that with the larger size of bulbs, the varieties of Bentanis, Bima Brebes and Tajuk had more food reserves, which affected the growth of plant height. On the other hand, the Ilokos and Sumenep varieties had a greater number of leaves and tillers than the other three varieties.

The quantitative character of flowering was controlled by many genes and is also influenced by environmental factors.

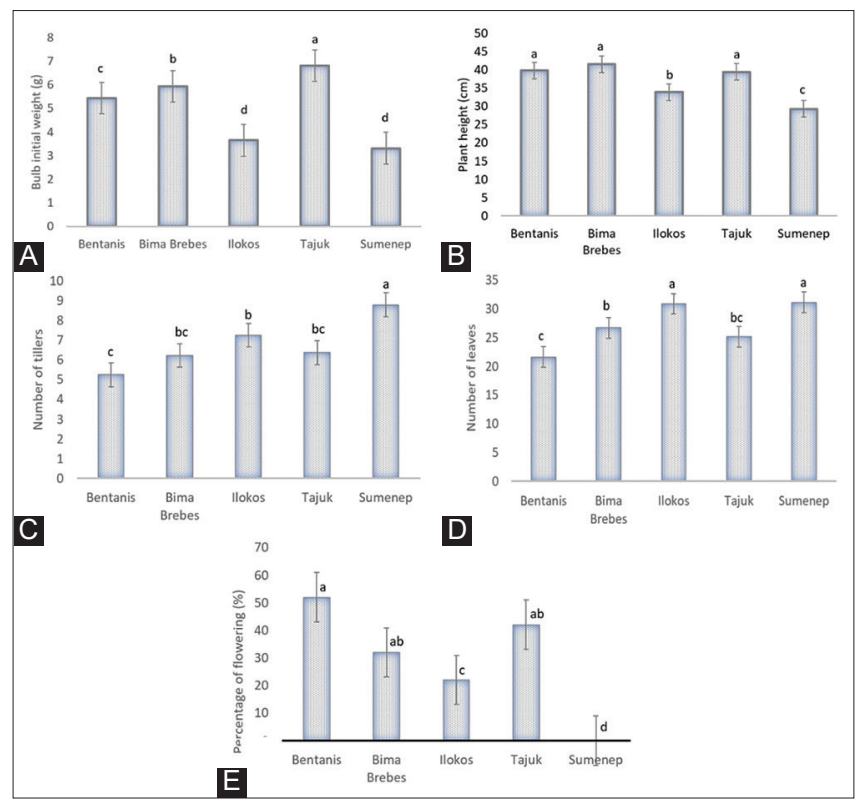

Fig 2. Efrfect of variety on bulb initial weight $(A)$, plant height (B), number of tillers (C), number of leaves (D), and percent of flowering (E) of shallots. Same letters within each variable response indicated no significant differences by LSD test at $5 \%$ level. Values are means with standard deviation of triplicate determinations.
The percent flowering of shallot was strongly influenced by variety and vernalization, but no interaction was found. Bentanis variety has the same flowering percentage as Bima Brebes and Tajuk, which is around $32-52 \%$, while the Ilokos variety has $22 \%$ flowering percentage, and the Sumenep variety has no flowering ability.

The results showed that the vernalization treatment singly had a very significant effect on the character of the initial bulb weight and the percentage of flowering (Fig. 3). The results showed that the plant height, the number of tillers, and the percentage of shallot flowering actually increased with the vernalization treatment. However, the vernalization treatment reduced the bulb initial weight.

Vernalization was an important adaptation of plants to initiate flowering in response to prolonged exposure to low temperatures (Finnegan et al., 2001; Song et al., 2012). The vernalization treatment had a stressful effect on plants which caused the plants to use more energy during their early growth period. The bulbs without vernalization treatment still store a lot of energy that can be used for optimal growth. Wu et al. (2016) stated that the vernalization in garlic inhibited the number of leaf, pseudostem diameter, and plant height. The vernalization of garlic bulbs at $4^{\circ} \mathrm{C}$ (for 2 months) resulted in bolting, inflorescence formation and true seed production in 9 varieties whereas non-vernalized failed to result into bolting, i.e. no true seed production was determined.

Cluster analysis showed that 5 varieties of shallot were divided into 3 groups according to the similarity of morphological and flowering characters (Fig. 4). The 3 patterns of flowering ability in shallot varieties, namely natural (sensitive flowering), medium sensitive, and non sensitive flowering ability. The natural flowering ability in shallot shown by the ability to flower naturally in shallot varieties with or without external stimulation. The medium sensitive variety of shallot will produce flowers in the presence of stimulation from external treatments, such as

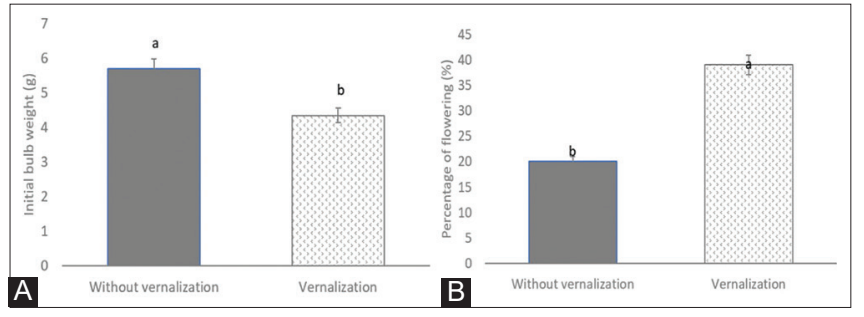

Fig 3. The effect of vernalixzation on bulb initial weight $(A)$ and percent of flowering $(B)$ of shallots. The numbers followed by the difference lowercase letter are significantly different based on the LSD test at $5 \%$ level. The numbers followed by the difference capital letter are significantly different based on the LSD test at $5 \%$ level. Values aremeans with standard deviation of triplicate determinations 


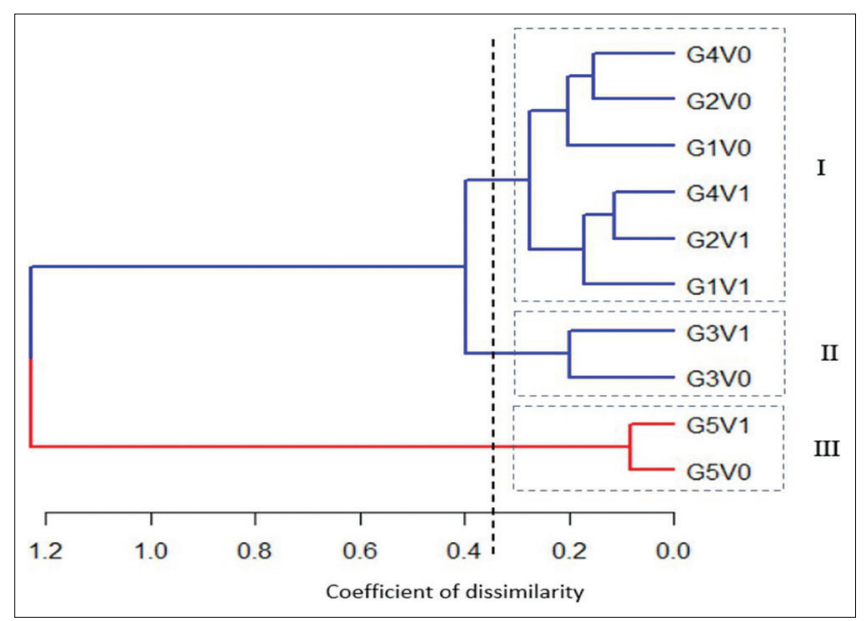

Fig 4. Herarchical cluster of the dissimilarity matrix of vernalization treatments of 5 shallot varieties. Without vernalization (v0), and vernalization (v1). Variety of Benatanis (G1), Bima Brebes (G2), llokos (G3), Tajuk (G4), Sumenep (G5)

vernalization. Meanwhile, a non-sensitive variety was not able to produce flowers naturally even with external stimuli.

The clustering of morphological and quantitative flowering characters was visualized graphically with a matrix representation of the degree of dissimilarity between the 5 local variety of shallot. The 5 varieties of shallot were grouped into 3 groups based on their flowering ability with similar morphological and quantitative flowering characters in which were given vernalization treatment and without vernalization treatment. The first group consisted of variety Bentanis (G1), Bima Brebes (G2), and Tajuk (G4). In the second group there was the Ilokos (G3) variety, and in the third group there was Sumenep (G5) variety. Each variety in the same group were similar based on morphological and flowering characters. Analysis of the 12 morphological and quantitative flowering characters of shallot further confirmed the different ability patterns of the tested shallot variety. The difference in the grouping of the 5 shallot varieties indicates that there are morphological and flowering variations among the five varieties, especially in terms of their flowering competence.

The results showed that the Sumenep variety had a different flowering pattern with other varieties, both without vernalization and with vernalization treatment. The Sumenep variety had the highest dissimilarity value compared to other varieties. The large disimilarity value indicated that the Sumenep variety has the different morphological and flowering characters from others. The Sumenep variety is a non sensitive flowering variety, even with the induction treatment such as vernalization treatment. Sumenep varieties are generally difficult to produce flowers (Idhan et al., 2015), The ideal grouping of varieties is when all the varieties in a group have a dissimilarity value equal to zero, but with varieties from other groups the dissimilarity value is equal to one. Identification of the morphological diversity and flowering ability of shallot is very useful knowledge in the efforts of onion breeding and cultivation development programs.

\section{CONCLUSIONS}

The $\mathrm{GA}_{3}$ can increase the yield of shallot by promoting shoot growth and bulb initiation. With the application of $\mathrm{GA}_{3}$ up to $100 \mathrm{mg} \mathrm{L}^{-1}$, the height of plants reached from 44.61 to $45.74 \mathrm{~cm}$. Tajuk variety showed better yield characters compared to other varieties which was observed in bulb number, bulb fresh weight, and bulb net weight of 9.41 bulbs/plant, $90.1 \mathrm{gram} / \mathrm{plant}$, and 75 gram/plant, respectively. Five varieties of shallot were clustered into 3 groups according to the similarity of morphological and flowering characters, namely very responsive included Bentanis, Bima Brebes, and Tajuk; medium responsive included Ilokos; and non-responsive included Sumenep.

\section{ACKNOWLEDGEMENT}

This researchs is supported by Institutional Research Grants in Bengkulu University, Indonesia (Unggulan Schema with contract number: 997/UN30.15/PG/2020).

\section{Authors contribution statement}

Marlin Marlin and Hartal Hartal designed and performed experiments. Marlin Marlin performed data analysis was in charge of the overall direction and planning, writing, and interpretation of the manuscript and interpretation of results. Atra Romeida and Reny Herawati participated in data collection and statistical analysis. Marulak Simarmata and other authors were involved in writing and review the article.

\section{REFERENCES}

Corbesier, L. and G. Coupland. 2006. The quest for florigen: Review of recent progress. J. Exp. Bot. 57: 3395-3403.

Elsiddig, E. A. M., O. M. Elamin and M. E. Elkashif. 2015. Induction of flowering in texas early grano onion cultivar using vernalization and gibberellic acid under gezira state Conditions, Sudan. Int. J. Sci. Res. Publ. 5: 1-7.

Farhadi, N. and S. A. Salteh. 2018. The effect of Forchlorfenuron on bulblet formation, antioxidant characteristics and phytochemicals compounds of Persian shallot (Allium hirtifolium.). J. Hortic. Sci. 31: 565-576.

Finnegan, E. J., D. Bagnall, C. Helliwell, D. Rouse, C. Sheldon, M. Tadege, W. J. Peacock and E. Dennis. 2001. Vernalization. Encyclopedia of Life Sciences Macmillan Publishers Ltd., Nature Publishing Group, Berlin, Germany. Available from: https://www. els.net. [Last accessed on 2016 Jan 12].

Helaly, A. A., M. S. Abdelghafar, M. T. Al-Abd and A. A. Alkharpotly. 
2016. Effect of soaked Allium cepa L. bulbs in growth regulators on their growth and seeds production. Adv. Plants Agric. Res. 4: 00139.

Hye, A. M., M. S. Haque and M. A. Karim. 2002. Influence of growth regulators and their time of application on yield of onion. Pak. J. Biol. Sci. 5: 1021-1023. Available from: https://www.scialert.net/ abstract/?doi=pjbs.2002.1021.1023.

Khokhar, K. M. 2014. Flowering and seed development in onion-a review. Open Access Libr. J. 1: 1-13. Available from: http://www. creativecommons.org/licenses/by/4.0.

Kucera, B., M. C. Cohn and G. Leubner-Metzger. 2005. Plant hormone interactions during seed dormancy release and germination. Seed Sci. Res. 15: 281-307. Available from: http:// www.seedbiology.de.

Kusumadewi, S., Hamim and Sobir. 2017. Photoperiods and Vernalization Study for Induction of Shallot Flowering (Allium cepa L. Aggregatum Group) in Lowlands, Thesis. IPB University, Bogor, Indonesia.

Lee, R., S. Baldwin, F. Kenel, J. McCallum and R. Macknight. 2013. Flowering locus $T$ genes control onion bulb formation and flowering. Nat. Commun. 4: 2884.

Mardiana, M. 2016. Effect of low temperature storage of shallot (Allium ascalonicum L.) seeds on seed growth. J. Keteknikan Pertanian. 4: 67-74.

Marlin, M., A. Maharijaya, A. Purwito and S. Sobir. 2019. Secondary metabolites change under vernalization and its relation to flowering competency in shallot (Allium cepa var. Aggregatum). Rasayan J. Chem. 12: 1418-1425.

Marlin, M., A. Maharijaya, A. Purwito and S. Sobir. 2018. Molecular diversity of the flowering related gene (LEAFY) on shallot (Allium cepa var. Aggregatum) and Allium relatives. SABRAO J. Breed. Genet. 50: 313-328. Available from: http://www.sabraojournal. org/sabrao-journal-of-breeding-and-genetics-volume-50number-3-september-2018.

Mohammadi-Motlagh, H., A. Mostafaie and K. Mansouri. 2011. Anticancer and anti-inflammatory activities of shallot (Allium ascalonicum) extract. Arch. Med. Sci. 1: 38-44.

Olszewski, N., T. P. Sun and F. Gubler. 2002. Gibberellin signaling: Biosynthesis, catabolism, and response pathways. Plant Cell. 14: S61-S80.

Ouzounidou, G., A. Giannakoula, M. Asfi and I. Ilias. 2011. Differential response of onion and garlic agenest plant growth regulator.
Pak. J. Bot. 43: 2051-2057.

Patel. M. J., H. C. Patel and J. C. Chavda. 2010. Influence of plant growth regulators and their application methods on yield and quality of onion (Allium cepa L.). Asian J. Hortic. 5: 263-265.

Rahman, M. H., M. S. Haque, M. A. Karim and M. Ahmed. 2006. Effects of gibberellic acid $\left(\mathrm{GA}_{3}\right)$ on breaking dormancy in garlic (Allium sativum L.). Int. J. Agric. Biol. 8: 63-65. Available from: http://www.fspublishers.org.

Shaikh, A. M. B., S. Vyakaranahal, M. Shekhargouda and P. R. Dharmati. 2002. Influence of bulb size and growth regulators on growth, seed yield and quality of onion cv. Nasik Red. Seed Res. 30: 223-229.

Singh, H. D., S. Maji and S. Kumar. 2014. Influence of plant bioregulators on growth and yield of garlic (Allium sativum L.). Int. J. Agric. Sci. 10: 546-549.

Song, J., A. Angel, M. Howard and C. Dea. 2012. Vernalization-a cold-induced epigenetic switch. J. Cell Sci. 125: 3723-3731.

Sravani, V., S. N. Saravaiya, B. N. Patel, H. N. Chhatrola, H. B. Patel and J. M. Vashi. 2020. Response of plant bioregulators on growth parameters and plant growth analysis of onion (Allium cepa L.). Int. J. Chem. Stud. 8: 1312-1316.

Sumarni, N., Suwandi, N. Gunaeni, S. Putrasameja. 2013. Effect of varieties and application of GA3 on flowering and yield of shallot seeds in the highlands of South Sulawesi, Indonesia. J. Hortic. 23: 153-163.

Tendaj, M. and B. Mysiak. 2013. The effect of summer seedling planting dates on the development of seed stalks in shallot (Allium cepa L. var. ascalonicum Backer.). Acta Sci. Pol. 12: 57-66. Available from: http://www.hortorumcultus.actapol.net/ volume12/issue6/12_6_57.pdf.

Tiwari, R. S., A. Ankur and S. C. Sengar. 2003. Effect of bioregulators on growth, bulb yield, quality and storability of onion cv. Pusa red. Indian J. Plant Physiol. 8: 411-413. Available from: http:// www.ispponline.org/storage/ijpp-8-4-020.pdf.

Wen, Z., W. Guo, J. Li, H. Lin,. C. He, Y. Liu, Q. Zhang and Q. Liu. 2017. Comparative transciptomic analysis of vernalization-and cytokinin-induced floral transition in Dendrobium nobile. Sci. Rep. 7: 45748.

Wu, C., M. Wang, Y. Dong, Z. Cheng and H. Meng. 2015. Growth, bolting and yield of garlic (Allium sativum $\mathrm{L}$.) in response to clove chilling treatment. Sci. Hortic. 194: 43-52.

Yamaguchi, S. 2008. Gibberellin metabolism and its regulation. Annu. Rev. Plant Biol. 59: 225-251. 